\title{
Birinci El Kaynaklara Göre Isparta Depremleri (19. Yüzyılın İkinci Yarısı)*
}

\author{
Dr. Öğr. Üyesi Selahattin Satılmış \\ Aksaray Üniversitesi Fen Edebiyat Fakültesi \\ Tarih Bölümü \\ sselahattin2003@hotmail.com
}

Öz

Bir devletin veya kentin sosyal ve iktisat tarihinin tam olarak anlaşılabilmesi için doğal afetlerin etkilerinin de ortaya konulması gerekir. Çünkü yaşanan büyük doğal afetler neticesinde zarara uğrayan insanlar, yerleşim birimleri, çevre ve ekonomik faaliyetler afet öncesi eski durumlarına dönememekte ya da bu süreç uzun zaman almaktadır. Bu çalışmada, birinci derece deprem bölgesinde yer alan Isparta ili ve ilçelerinde 19. yüzyılın ikinci yarısı boyunca meydana gelen depremler, birinci el kaynaklardan olan arşiv belgeleri, gazeteler ve kroniklerin ışığında ele alınmış; ne sıklıkla ve büyüklükte yer sarsıntılarının yaşandığı ortaya çıkarılmak suretiyle Isparta'nın deprem tarihine ve depremselliğine katkıda bulunulması hedeflenmiştir. Bu bağlamda Isparta'da 19. yüzyılın ikinci yarısında yirmi beş depremin yaşandığı tespit edilmiştir. Hasara yol açan beş deprem içerisinde en etkilisi 17 Ocak 1889 depremi olup, Isparta kent merkezi ile bazı köylerinde çok sayıda binanın harap olmasıyla sonuçlanmıştır. Bu yıkıcı deprem sonrasında Isparta mutasarrıfının başkanlığında bir Afet Komisyonu kurulmuştur. Sorunlara ve ihtiyaçlara acil çözümler bulmayı hedefleyen komisyon, kısa bir süre içerisinde depremzedelerin yaralarını sarmaya çalışmıştır.

Anahtar Kelimeler: Doğal afet, deprem, Osmanlı Devleti, Isparta, Yalvaç.

\section{Isparta Earthquakes according to the Primary Sources (Second Half of the $19^{\text {th }}$ Century)}

\begin{abstract}
Natural disasters are significant socio-economic events that concern people and states. This is because it is not possible or takes a long time for the people, the settlement units, the environment and the economic activities to return to the pre-disaster conditions due to the significant natural disasters. For this reason, the effects of natural disasters need to be revealed for a complete understanding of the social and economic history of a state or city. In this study, the earthquakes that took place during the second half of the 19th century in the Isparta provinces and districts located in the first-degree earthquake region were discussed in the light of primary sources, which are archive documents, newspapers and chronicles. In this way, it has been aimed to contribute to the seismicity and Isparta's
\end{abstract}

* Bu makale, TÜBİTAK'ın desteklediği 113K146 nolu ve “19. Yüzyıl Türkiye Deprem Tarihi ve Sosyo-Ekonomik Etkileri" başlıkıı SOBAG Projesi kapsamında hazırlanmıştır.

Gönderim Tarihi / Sending Date: 13/04/2018 Kabul Tarihi / Acceptance Date: 26/06/2018 
earthquake history by revealing how frequently and large earthquakes were experienced. In this context, during the second half of the 19th century in Isparta, it was determined that twenty-five earthquakes occured, several of which seemed to have caused damage. Especially on 17 January 1889, the earthquake was very severe. So, several buildings in Isparta city centre and some villages connected here were ruined. After this devastating earthquake, a Disaster Commission was established under the chairmanship of Isparta tenant (mutasarrif). The Commission aimed to find urgent solutions to the problems and needs, and attempted to cover the wounds of the earthquake victims within a short period of time.

Keywords: Natural disaster, earthquake, Ottoman State, Isparta, Yalvaç. 


\section{GIRIŞ: ISPARTA'NIN DEPREMSELLİĞİ}

Deprem, doğal etkenlere bağlı olarak yer kabuğunda görülen ve şiddetli gerçekleştiğinde yeryüzünde önemli değişiklere neden olan, kısa süreli salınım ve titreşim hareketleridir. Dünya üzerindeki kıta levhaları devamlı hareket halinde olup, bazı bölgelerde birbirleriyle çarpışmaktadır. Tektonik hareketler sırasında levhaların birbirine sürtünmesinden dolayı biriken potansiyel enerji, kırılma neticesinde hareket enerjisine dönüşmekte ve açığa çıkan olağanüstü boyuttaki bu enerjinin dalgalar halinde çevreye yayılmasıyla depremler (sarsıntılar, şok dalgaları) meydana gelmektedir. (Şahin-Sipahioğlu 2009: 26; Özey 2011: 26).

Anadolu'nun batıya doğru hareketi ve Afrika levhasının Girit Adası yayı altına dalması, doğu-batı yönlü sıkışmalara yol açarken, kuzey-güney yönlü genişlemeyi de beraberinde getirmektedir. Bu hareket aynı zamanda Isparta-Burdur yöresindeki fay sistemlerinin domino taşları gibi kıpırdamasına yol açmaktadır. Sismolojik açıdan Akdeniz Deprem Kuşağı'nda yer alan Isparta, Ege/Helen Hendeği, bunun doğu uzantısı olan Kıbrıs Yayı ve Ege Graben Sistemi'nin üçlü denetimi altında bulunmaktadır. Yöre aynı zamanda Beyşehir Gölü, Sultanhisar, Eğirdir Gölü ve Burdur faylarını barındırmaktadır. Diğer bir ifadeyle yöre, faylarla parçalanmış durumdadır (Sezer 2000: 76).

Isparta ve çevresi, fay hatlarının oluşturduğu şekil bakımından Isparta üçgeni ya da Isparta büklümü olarak adlandırılır. Isparta üçgeninin batısı Burdur-Fethiye Zonu (BFZ), doğusu Akşehir Fayı tarafından sınırlanır. Isparta şehri ise üçgenin üst kısımlarında BurdurFethiye Zonu'nun Akşehir Fayı ile kesiştiği noktanın altında yer alır. Ayrıca Isparta'nın da içinde yer aldığ 1 Göller Bölgesi, graben sistemine sahiptir. Isparta'nın doğusunda yer alan Eğirdir ve Beyşehir Gölleri ile batısındaki Burdur Gölü, çöküntü gölleridir. Eğirdir Gölü'nün kuzeyinde bulunan Hoyran kesimi ise yan atımlı bir fay ile sınırlanmıştır. Bu nedenle öncü şoklar, özellikle de graben sistemlerine sahip bölgelerde yaşananlar, ana depremin şiddetini azaltmaktadır ki, bu durum, Isparta ve çevresi için bir avantaj görünmektedir (GörmüşKanbur vd. 2010: 23-30).

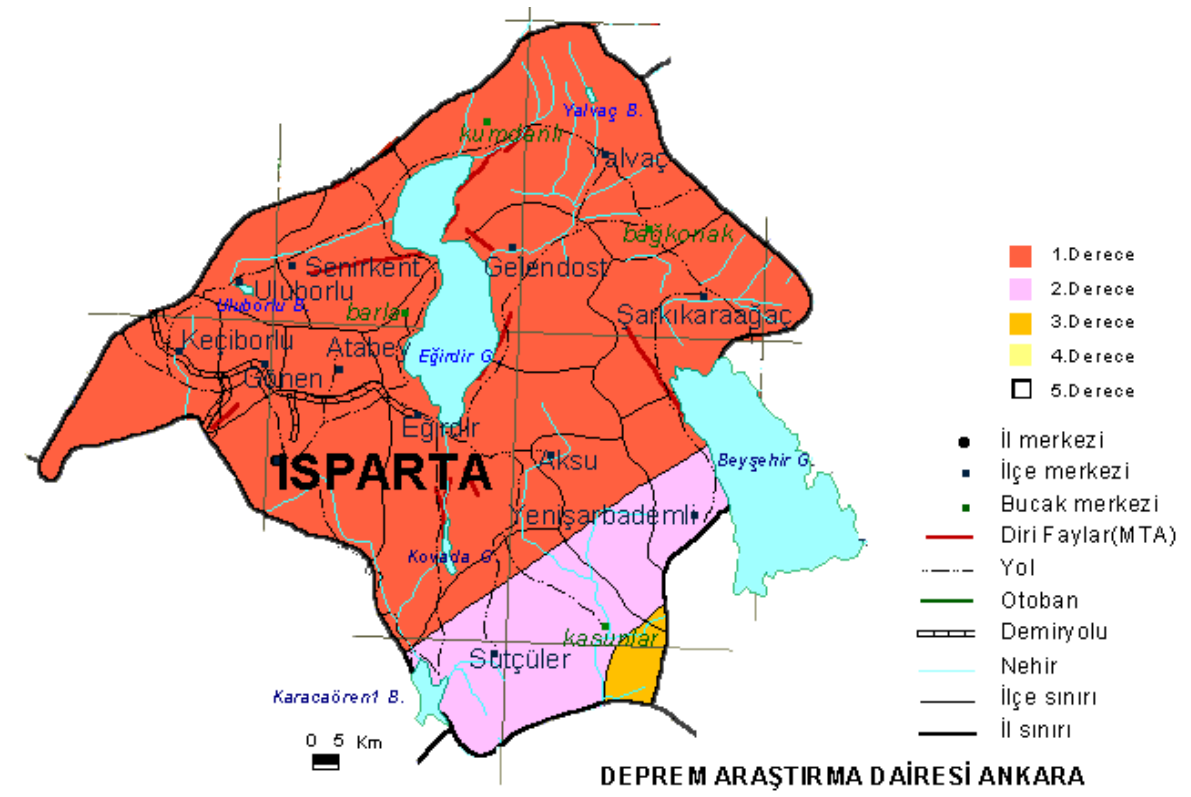

Şekil 1: Isparta deprem haritası (http://www.e-sehir.com/turkiye-haritasi/isparta-deprem-fay-hattiriskharitasi.html 6.02.2018, 10:15) 
Isparta ve civarı, kireç taşları ve dolomitlerden oluşan karbonatlı kayaçlarla kaplı olup, aktif fayları da barındırmaktadır. Ayrıca Isparta şehrinin bir kısmı, su tablası yüzeye yakın olan alüvyon dolgulu ova üzerine kuruludur. Bu açıdan Fatih, Anadolu, Davraz, Zafer ve Vatan mahalleleri depremde en fazla zarar görme ihtimali olan yerlerdir. Binbirevler ve Mavikent mahalleleri de zeminlerinin volkanoklastik yapıdaki kül tüflerden oluşmasından dolayı deprem açısından sakıncalı yerlerdir. Bu tür yerlerde zemin pekleşmemesinden yani dokusunun gevşek olmasından dolayı deprem diğer yerlere nispeten daha şiddetli hissedilmekte ve daha büyük zarara yol açmaktadır (Sargın 2004: 376-378).

Kullanılan inşaat malzemeleri ile yapıların depremlere karşı gösterdiği direnç arasında doğru orantı bulunmaktadır. Bu bağlamda 19. yüzyılda Isparta'daki evlerin bir kısmının tuğladan yapılmaya ve üzerlerinin çatı ile örtülmeye başlanması, bu yapıların depremlere karşı gösterdiği direnci artırmıştı. Bununla birlikte aynı yüzyılda Isparta'da temelden çatıya kadar taş ve molozla inşa edilen, harç malzemesi olarak da toprak kullanılan toprak damlı eski evlerin kullanılmaya devam etmesi, depremler karşısında daha fazla risk barındırmaktaydı (Böcüzâde Süleyman Sami 2012: 35).

Rivayetlere göre, Isparta ve deprem arasındaki ilişki çok güçlü olup, milattan önceki tarihlere kadar gitmektedir. Öyle ki, Isparta'nın şehir olarak kurulması ve bu ismi alması, M.Ö. IV. asırda meydana gelen büyük bir depremle alakalıdır. Rivayete göre Yunanistan'da bulunan Sparta (Isparta) şehrinin bahsi geçen bu depremde harap olması sonucu sakinlerinden bir kısmı, kendi şehirlerinin baskın havasından dolayı yazları yayla olarak kullandıkları bu bölgeye göç ederek yerleşmiş; kasabayı kuşatan dağlara ve dere içlerine evler ile mabetler inşa etmiş ve geldikleri şehrin ismini buraya taşımışlardır (Böcüzâde Süleyman Sami 2012: 10).

Başka bir rivayet ise eskiden bir dere yatağı olan Isparta kasabasının dümdüz hale gelmesine, bu bölgede milattan önce meydana gelen şiddetli bir depremin yol açtığ yönündedir. Isparta'ya bir buçuk saat yürüyüş mesafesinde, Gölcük Tepeleri arasında derin, suyu gayet güzel ve tatlı olan bir göl, bahsi geçen depremde mecrasının (su yolunun) kapanması nedeniyle taşmış ve Isparta'nın bulunduğu dereyi göl haline getirmiştir. Daha sonra meydana gelen başka bir şiddetli depremde ise Gölcük suyunun eski mecrasının açılması ve kaynağının kesilmesiyle Kuleönü köyüne kadar uzanan bu gölün bulunduğu saha kurumaya yüz tutmuştur. Bu süreçte şehrin yer aldığı dere içi dolmuş ve dümdüz olmuştur (Böcüzâde Süleyman Sami 2012: 14).

Osmanlı deprem bilimi, 19. yüzyılda çok gerilerdeydi. Takiyüddin Rasathanesinin 1580 yılında topa tutularak yıkılmasından sonra yeni rasathane ancak 1868 'de inşa edilmişti. Rasatahane-i Amire ismiyle kurulan bu kurum da astronomi rasathanesi olarak değil, meteoroloji merkezi olarak düşünülmüştü. Bununla birlikte Osmanlı Devleti'nde 10 Temmuz 1894 Marmara depremi sonrasında deprem bilimine ilgi artmaya başlamış ve bu konuda bazı önemli gelişmeler yaşanmıştır. Padişah II. Abdülhamit, bu deprem sonrasında Marmara Denizi'nde araştırma yaptırmak ve Osmanlı bilim adamlarını deprem konusunda eğitmek üzere Atina Rasathanesi müdürü Eignitis (Ejnitis) İstanbul'a davet etmiştir. (Ünver 2014: 18-19; Dizer 1973: 18-19; Sakin 2009: 343; http://www.koeri.boun.edu.tr/140yil/Tr/kandilli.asp?PageName=tarihce; Yine ayn deprem sonrasında padişah birisi İstanbul Rasathanesine, diğeri Yıldız Sarayı'nın bahçesinde kurulmak üzere iki adet sismograf cihazı sipariş etmeye karar vermiştir (BOA, İ.HUS., 26/63, 14 M 1312; BEO., 508/38081, 4 CA 1312; 513/38438, 11 CA 1312). Ancak bu cihazlar altı yıl 
kadar sonra temin edilebilmiş ve XX. yüzyılın başlarından itibaren Osmanlı Devleti'nde depremin meydana geldiğini tespit eden ve büyüklüğünü belirleyen bir alet kullanılmaya başlanmıştır (Ambraseys 2009: 767).

XIX. yüzyılda Osmanlı Devleti'nde büyük felaketlere maruz kalan afetzedelerle ilgilenen hali hazırda bir kurum bulunmamaktayd. Temelleri 1868 'de atılan ve eski ismi Hilâl-i Ahmer Cemiyeti olan Türkiye Kızılay Cemiyeti ilk olarak 1912 yılında meydana gelen Mürefte depreminde afetzedelerle ilgilenmeye başlamıştır. 19. yüzyılın ikinci yarısında depreme maruz kalan afetzedelerin yaralarının sarılması için Sultan Abdülmecit ve Sultan Abdülaziz dönemlerinde, padişahlar yüklü miktarda paralar ihsan etmekte, devlet hazinesinden harcamalar yapılmakta ve vilâyet çapında yardım kampanyaları düzenlenmekteydi. II. Abdülhamit döneminde ise daha çok bütün memleket düzeyinde düzenlenen yardım kampanyaları neticesinde toplanan büyük meblağlar sayesinde depremzedelerin yaraları sarılmakta idi (Ceride-i Havâdis, 733-738: 28 C-8 Ş 1271; Yazıcı 2003: 57-61; BOA, Y.MTV., 197/36, 5 Ş 1317; DH.MKT., 2252/27, 22 CA 1317).

\section{ISPARTA TARIHHINDE DEPREMLER (19. YÜZYILIN İKINCI YARISI)}

Arşiv belgeleri, gazeteler, kronikler gibi birinci el kaynaklar üzerinden yaptığımız incelemeler neticesinde, 19. yüzyılın ikinci yarısında Isparta ve ilçelerinde yirmi beş defa deprem yaşandığını tespit edilebilmiştir.

\section{Mayıs 1851 Pavlu (Sütçüler) Depremi}

Ramazan ayının on yedinci günü meydana gelen bu deprem, Hamit (Isparta) sancağına bağlı Sütçüler'de etkili olmuştur. Deprem sırasında Sefer Ağa Camii'nin kubbesi birkaç yerinden çatlamış ve kubbeden taşlar düşmüştür. Bir süredir tamir edilmemesi nedeniyle harap olmaya yüz tutan camide ibadet etmek tehlikeli hale gelmiştir. Öyle ki Sütçüler halkının kaleme aldığı arzuhalde "namaz kılarken ne derece havf (korku) yaşandığının tarife gelmeyeceği" ifade edilmişti. Bu cami, o dönemde Pavlu kazası ve civarındaki Müslümanların cuma ve bayram namazlarını kıldığı tek ibadethane olması itibariyle çok önemliydi. Öyle ki, camide kılınması farz olan bu namazlar için Sütçüler'e üçsekiz saat arası mesafedeki köylerden insanlar gelmekteydi. Dolayısıyla caminin kubbelerinin tamir edilmesi elzemdi. Yapilan incelemeler neticesinde kubbelerin tamir masrafının bin kese akçeyi geçeceği tahmin edilmişti. Bu büyük rakamı karşılayabilmek için Sütçüler halkı Padişaha hitaben bir arzuhal kaleme almış ve deprem sırasında harap olan camilerinin tamir masraflarının karşılanmasını istirham etmişti (BOA (Başbakanlık Osmanlı Arşivi-BOA.,-A.MKT.DV, 38/68, 29 Ş 1267). Aynı deprem Isparta'da da şiddetli derecede hissedilmiş olmakla birlikte burada hasara yol açmamıştır (Ceride-i Havâdis, 534: 6 Ş 1267). $\mathrm{Bu}$ arada depremin Sütçüler'de sağlam yapılardan biri olan camide hasara yol açması, bu civardaki evlerde de hasara yol açmış olabileceği ihtimalini düşündürmektedir.

\section{Mayis 1858 Isparta Depremi}

Deprem, akşam ezanından üç saat on beş dakika sonra şiddetli bir şekilde meydana gelmiştir. Bir dakika kadar süren deprem, hasara yol açmamıştır (Ceride-i Havâdis, 863: 14 R 1274).

\section{Eylül 1861 Isparta Depremi}

Deprem, gece vakti, alaturka saat 8.00 sularında yaşanmış ve ardından bir defa artçı şoku meydana gelmiştir. Deprem hasara yol açmasa da, oldukça şiddetli derecede 
yaşanmasından dolayı Isparta halkını büyük korku ve endişeye sevk etmiştir (Ceride-i Havâdis, 1059: 24 RA 1278).

\section{Ocak 1863 Yalvaç Depremi}

Konya' da hafif derecede hissedilen bu deprem, Hamit (Isparta) sancağına bağlı Yalvaç kazasında "şiddetlice" yaşanmıştır. Depremin şiddeti ve birbirini müteakip arţ̧ı şoklarının yaşanması nedeniyle korkan Yalvaç halkı, evlerini terk ederek açık alanlara çıkmıştır. Depremler her iki yerleşim biriminde de hasara yol açmamıştır. 7 Ocak 1863 tarihli Ruzname-i Ceride-i Havadis gazetesinin "Şu esnada Konya'da bir iki defa hareketi arz vukubulmuş" ifadesinden depremin 5 ya da 6 Ocak'ta yaşandığı tahmin edilebilir (Ruznâme-i Ceride-i Havâdis, 545: 16 B 1279; Takvim-i Vekâyi, 678: 21 B 1279).

\section{Ağustos 1868 Isparta Depremi}

Perşembe günü, alaturka saat 5.00 sularında Isparta'da yaşanan bu deprem, arşiv belgesindeki ifadeyle "biraz şiddetlice" gerçekleşmiş ancak herhangi bir hasara yol açmamıştır. Ana depremden yarım saat kadar önce daha az şiddetli bir öncü şok yaşanmıştır (BOA, A.MKT.MHM., 420/87, 04 C 1285).

\section{4-5 Eylül 1868 Isparta Depremi}

Isparta'da iki defa yaşanan depremlerden birincisi 4 Eylül Perşembe gecesi alaturka saatle $4.30^{\prime} \mathrm{da}$ (23.31), ikincisi ise alaturka saat $8.00^{\prime}$ de (5 Eylül Cuma gecesi saat $03.31^{\prime} \mathrm{de}$ ) meydana gelmiştir. İki deprem de hasara yol açmamıştır (BOA, A.MKT.MHM., 422/22, 12 C 1285).

\section{Ocak 1874 Isparta Depremi}

Deprem, Isparta'da gece yarısı çok şiddetli derecede yaşanmışsa da hasara yol açmamıştır. Aynı deprem Burdur'da hafif şiddetli derecede hissedilmiştir (The Levant Herald, Vol III, 4: 28 Ocak 1874).

\section{Mayıs 1875 Isparta Depremi}

Deprem, akşam ezanından iki saat kadar sonra şiddetli derecede meydana gelmişse de hasara yol açmamıştır. Dört saniye süren depremin sabaha kadar üç defa arţ̧ı şoku yaşanmıştır (Basiret, 1528-1535: 13-21 R 1292).

\section{Mayıs 1875 Isparta Depremi}

Basiret gazetesi, 29 Mayıs 1875 tarihli nüshasında Isparta'da şiddetli bir deprem meydana geldiğinden bahsetmişse de kesin tarihini vermemiştir. İki saniye süren ve hasara yol açmayan bu depremin sabaha kadar arţ̧ı şokları yaşanmıştır (Basiret, 1540: 23 R 1292).

\section{Aralık 1883 Keçiborlu Depremi}

Hamit (Isparta) livasına bağlı Keçiborlu nahiyesinde etkili olan bu deprem, Salı gecesi alaturka saat 00:30'da yani akşam ezanından yarım saat sonra meydana gelmiştir. Depremde nahiyede bulunan Vakıf Han'ın sağ tarafı tamamen yıkılmış ve bu binanın enkazı altında kalan Hüseyin b. Osman isimli bir kişi hayatını kaybederken, 2 deve telef olmuştur. Bunun dışında herhangi bir hasar meydana gelmediği kayıtlara geçmiştir (BOA,Y.PRK.DH., 1/64, 12 S 1301). 


\section{Kasım 1885 Isparta Depremi}

Bu deprem şiddetli derecede kendisini hissettirmesine rağmen hasara yol açmamıştır (Tarik, sayı 593, 10 S 1303).

\section{Eylül 1887 Isparta Depremi}

Konya Valisi Memduh Bey'in verdiği bilgilere göre, deprem alaturka saat 4.05'te şiddetli bir şekilde meydana gelmiş ve uzun bir süre devam etmiştir. Bu depremden 11 dakika sonra bir artçı şok yaşanmıştır. Deprem Isparta'nın yanı sıra saat 4.12' de Burdur'da da yaşanmış ve burada otuz saniye kadar sürmüştür. Yaşanan depremler hasara yol açmamıştır (BOA., Y.A.HUS., 207/30, 14 M 1305). Aslında bu depremler, aynı gün alaturka saat 04.00'te Uşak kazasına bağlı Banaz nahiyesi merkezli yaşanan ve bu civarda büyük hasara yol açan çok şiddetli bir depremin uzantılarıdır (Tarîk, 1272: 23 M 1305; BOA, Y.A.HUS, 207/83, 7 S 1305; Satılmış 2016: 79-98).

\section{Ocak 1889 Isparta Depremi}

Depremin Yol Açtığı Hasar ve Zâyiat: Deprem 16 Ocak'1 17 Ocak'a bağlayan gece, alaturka saat 9.30'da yaşanmış ve 5 saniye kadar sürmüştür. Arşiv belgesinde geçen “zelzeleden evvel bir sadâ-yı müdhiş işitilip uykuda olanlar havlulara çıkmış" ifadesinden ana deprem öncesinde bir öncü sarsıntının yaşandığı ve bu depreme eşlik eden gürültü sebebiyle halkın büyük bir korku ve endişe içerisinde uyanarak evlerinin dışına çıtığı anlaşılmaktadır. Bu bağlamda, öncü sarsıntının, çok sayıda evin yıkılmasına rağmen can kayıplarının asgari miktarda kalmasını sağladığı söylenebilir. Başka bir belgede ise Isparta halkını gece vakti uykuda yakalayan depremin şehrin güneybatısından esen bir fırtına sırasında, "top patlarcasına müthiş bir ses eşliğinde meydana geldiği”" ifade edilmiştir (BOA, Y.PRK.UM., 13/112, 16 CA 1306; Y.MTV., 37/36, 22 CA 1306). 17 Ocak depreminin geniş bir sahada hissedildiği görülmektedir. Öyle ki aynı saatte Bodrum ve çevresinde de şiddetli derecede bir deprem yaşanmış ve bu nedenle halk dağlara kaçmıştır (The Levant Herald, Vol IX, sayı 6, 10 Şubat 1889).

17 Ocak depreminin artçı şokları da meydana gelmiştir. Ana depremin yaşandığı gün, gündüz saat 8.00'e kadar hafif ve şiddetli yedi defa artçı şok yaşanırken, 17 Ocak gecesinde üç, 18 Ocak gündüzünde iki, gecesinde ise bir defa artçı şok yaşanmıştır. Hafif şiddetli gerçekleşen bu artçı şokların hiç birisi hasara yol açmamıştır. Isparta Mutasarrıfı Saadettin Bey'in $^{1}$ verdiği bilgilere göre depremin arkası, 4 Şubat 1889 tarihi itibariyle kesilmiştir (BOA,Y.PRK.UM., 13/112, 16 CA 1306; Y.PRK.UM., 14/2, 4 C 1306).

$\mathrm{Bu}$ afetin hemen akabinde Isparta'dan Konya Valiliğine gönderilen ilk bilgilerde depremin yol açtı̆̆ı zararın çok büyük olmadığı belirtilmişti (The Levant Herald, Vol 9, sayı 5, 3 Şubat 1889). Ancak gün 1şı̆̆ıyla birlikte depremin verdiği gerçek zarar anlaşılmış, meydana gelen hasarın çok daha fazla olduğu ortaya çıkmıştır. Öyle ki bu şiddetli deprem, Isparta şehir merkezinde Hacı Elfı (Pirimehmet) ve Şeyh (Kutlubey) mahallelerindeki evlerin tamamının yıkılmasına yol açarken, Sülübey, Emre, Tekye (Hızırbey), Cami-i Atik (Kutlubey) ve Yaylazade (Yayla) mahallelerindeki evlerin ise kısmen harap olmasıla sonuçlanmıştır (Böcüzâde Süleyman Sami 2012: 625-626). Hacı Elfi, Şeyh, Hacı Atik, Yaylazade mahalleleri ile Deregümü köyünde deprem nedeniyle 2 kişi hayatını kaybetmiş, 2

\footnotetext{
${ }^{1}$ Saadettin Bey, kıyafeten berber Çil Mahmut isimli bir zata çok benzediğinden, halk arasında isminden öte "Çil Mahmut" olarak tanınmıştı. Bu nedenle Isparta'da mutasarrıflık yaptığı dönemde yaşanan depremlerden bahsedilirken, Çil Mahmut zamanında denilirdi. (Böcüzâde Süleyman Sami 2012: 630).
}

SEFAD, 2018 (40): 297-312 
kişi yaralanmış², 252 bina tamamen ya da kısmen harap olarak, içinde oturulamaz hale gelmiştir. Sülübey ve Emre mahallelerinde ise 5 ev tamamen yıkılırken, 8 evin sokağa bakan duvarları tehlikeli olabilecek dereceye gelmiş, 45 ev ile 1 mescit ve 1 sıbyan mektebi tamir edilebilecek derecede hasar görmüştür. Şehir merkezinde bulunan hamam ile 10 dükkân da depremden zarar gören yerler arasındadır. Deprem, Isparta şehir merkezinin yanı sıra etrafındaki bazı köylerde de etkili olmuştur. Bu bağlamda depremden en fazla etkilenen köylerden birisi Deregümü'dür. Isparta'ya bir saat yürüyüş mesafesindeki bu köyde can kaybı yaşanmazken, 36 ev harap olmuş ya da çeşitli oranlarda hasar görmüştür. Ayrıca ismini tespit edemediğimiz bir köyün daha depremden etkilendiğini tarihsel kayıtlardan öğrenmekteyiz (BOA,Y.PRK.UM., 13/112, 16 CA 1306; Y.PRK.UM., 14/2, 4 C 1306; Y.MTV., 37/36, 22 CA 1306; The Levant Herald, Vol 9, sayı 5-6, 3-10 Şubat 1889).

Yukarıda bahsi geçen rakamların sadece yıkılan ya da ağır hasar gören evlerin sayısını yansıttığ1 anlaşılmaktadır. Öyle ki Sabah gazetesinin 29 Mayıs 1890 tarihli nüshasında Isparta'da depremzedelere ait 800 kadar evin yeniden inşa ya da tamir edildiğinden bahsedilmektedir. Bu bağlamda Isparta'da depremden hasar gören evlerin sayısının çok daha fazla olduğu ortaya çıkmaktadır. Diğer bir ifadeyle 500'e yakın evin de içerisinde oturulabilecek şekilde hafif derecede hasar gördüğünü söylemek mümkündür (Sabah, 269: 9 L 1307).

Arşiv belgeleri ve gazetelerin yanı sıra Böcüzâde Süleyman Sami de "Isparta Tarihi" isimli eserinde, 1889 depreminin bazı yapılarda yol açtığı zararlar hakkında önemli bilgiler vermektedir. Bu depremde en fazla zarar gören yapılardan birisi Keçeci Mahallesi'nde bulunan Hızır Bey Camii'dir ki, caminin hem kendisi hem de minaresi harap olmuştur. Yirmi yıl kadar harap bir halde kalan cami, 1910 yılında Isparta halkı arasında toplanan yardım paralarıyla daha geniş ve daha yüksek bir şekilde inşa edilmiştir. Aynı depremde hasar gören yapilardan bir diğeri de Çelebiler Mahallesi'yle Yaylazâde Mahallesi'nin birleşme noktasındaki Kaymak Kapısı ${ }^{3}$ civarında bulunan ve Peygamber Camii olarak da bilinen Abdi Paşa Camii'dir ki, minaresinin şerefesinden yukarısı yıkılmıştır. Çelebiler Mahallesi'nde bulunan medreseden birisi ve en eskisi olan Sadiye Bukasi'na ait, mescit olarak kullanılan kubbeli bir yapı da 1899 depreminde yıkılmaya meyilli hale gelmiştir. Bahsi geçen yapı tehlike arz etmesi nedeniyle yıktırılmıştır (Böcüzâde Süleyman Sami 2012: 125-149).

\footnotetext{
$\overline{2}$ Hayatını kaybedenler Hacı Elfı Mahallesi'nden Kavukçuzade Süleyman Efendi'nin on beş veya on altı yaşındaki kızı ile Tekye Mahallesi'nden Balcığlu Hacı Hafız'ın on beş veya on altı yaşındaki oğlu Hüsnü'dür. (BOA,Y.MTV., 37/36, 22 CA 1306)

${ }^{3}$ Kaymak Kapısı, Isparta çarşısının kaymak, yoğurt pazarındaki girişi olup sabahları bekçiler tarafından açılır, akşamları kapanır bir parmak kapıdan ibarettir. Bu kapı yol genişletmesi nedeniyle kaldırılmıştır. (Böcüzâde Süleyman Sami 2012: 125-149).
} 


\begin{tabular}{|c|c|c|c|c|c|c|}
\hline $\begin{array}{l}\text { Mahalle ya da } \\
\text { Köy İsmi }\end{array}$ & $\begin{array}{c}\text { Tamamen } \\
\text { Yikilan }\end{array}$ & $\begin{array}{l}\text { Kismen } \\
\text { Yikılan }\end{array}$ & $\begin{array}{l}\text { Tehlikeli } \\
\text { Hale } \\
\text { Gelerek } \\
\text { Yıktırılan }\end{array}$ & $\begin{array}{c}\text { Hafif } \\
\text { Derecede } \\
\text { Hasar } \\
\text { Gören }\end{array}$ & Toplam & $\begin{array}{l}\text { Masraf } \\
\text { (Kuruş) }\end{array}$ \\
\hline $\begin{array}{c}\text { Hacı Elfi } \\
\text { (Pirimehmet) ve } \\
\text { Şeyh } \\
\text { mahalleleri }\end{array}$ & 36 & 106 & 10 & & 152 & 66.275 \\
\hline $\begin{array}{c}\text { Cami-i Atik ve } \\
\text { Yaylazade } \\
\text { mahalleleri }\end{array}$ & 11 & 60 & 6 & & 77 & 29.070 \\
\hline $\begin{array}{l}\text { Deregümü } \\
\text { Köyü }\end{array}$ & 8 & 15 & & & 23 & 4.550 \\
\hline $\begin{array}{l}\text { Sülübey ve } \\
\text { Emre } \\
\text { mahalleleri }\end{array}$ & 5 & 47 & 8 & & 59 & 9.690 \\
\hline $\begin{array}{c}\text { Bütün mahalle } \\
\text { ve köyler }\end{array}$ & & & & 487 & 487 & $?$ \\
\hline Toplam & & & & & 800 & 99.895 \\
\hline
\end{tabular}

Tablo 1: 1889 depreminde Isparta' da meydana gelen hasar miktarı ve derecesi (BOA, Y.MTV., 37/36, 22 CA 1306; Y.PRK.UM., 14/2, 4 C 1306; Sabah, 269: 9 L 1307).

Afet Yönetimi: 1889 depreminin hemen ardından Isparta Mutasarrıfı Saadettin Bey'in yaptığ 1 ilk iş, bir afet komisyonu kurarak, hasar tespiti yaptırmak ve alınacak tedbirleri belirlemek olmuştur. Afet yönetimi, Isparta mutasarrıfının başkanlığında belediye meclis üyeleri, hayırseverler ve subaylardan oluşan on kişilik özel bir komisyon tarafından üstlenilmiştir (BOA, Y.MTV., 37/36, 22 CA 1306) ${ }^{4}$. Komisyon içerisinde özellikle Liva İdare Meclisi üyelerinden Bursalı Ahmet Efendi'nin depremzedelerin yaralarının sarılmasında büyük gayretlerinin görüldüğü dikkat çekmektedir (Böcüzâde Süleyman Sami 2012: 625626).

Afet Komisyonu'nun yaptı̆̆ı ilk iş, meydana gelen hasar ve zayiat miktarını öğrenmek amacıyla hemen deprem mahalline kol kol memurlar çıarmak olmuştur. Bu memurlar 19 Ocak 1889 tarihinden itibaren deprem bölgesinde incelemeler yaparak, beş gün boyunca hasar tespiti yapmışlardır. Memurların yanı sıra Isparta'da bulunan üç doktor da deprem bölgesine gönderilerek, yaralı afetzedelerin tedavisini gerçekleştirmişlerdir. Komisyon ayrıca afetzedelerin barınma ve beslenmeleri, tehlike arz eden binaların yıkılması, hasar gören binaların tamiri gibi birçok önemli görevi, acil bir şekilde yerine getirmeye çalışmıştır (BOA,Y.PRK.UM., 13/112, 16 CA 1306; Y.MTV., 37/36, 22 CA 1306).

\footnotetext{
${ }^{4}$ Afet komisyonunun diğer üyeleri şunlardır: Isparta Tâlî Taburu binbaşısı Esad Bey, Isparta Mukaddem Taburu kolağası Ali Rıza Efendi, Belediye Başkanı Hacı Hasan Efendi, Mukâvelât muharriri Hanzade Hacı Osman Efendi, Bidayet Mahkemesi mülâzımı Çallızade Mustafa Necib Efendi, Belediye Meclisi üyesi Dedezade Hacı Mehmed Efendi, Orman İdaresi kâtibi Böcüzade Osman Efendi, Rum ileri gelenlerinden Küçükzade Hacı Lazaros Efendi, Ermeni ileri gelenlerinden Menas Karabetyan Efendi, Belediye Meclisi kâtibi ve Belediye Meclisi sandık emini. (BOA, Y.MTV., 37/36, 22 CA 1306).
} 
Mutasarrıf Saadettin Bey, hem depremin yaşandığı gecenin sabahında hem de ertesi gün Isparta'da harap olan evleri teker teker dolaşmak suretiyle incelemelerde bulunmuş; depremden etkilenen aileleri teselli ederek umut vermeye çalışmıştır. Ayrıca bu inceleme gezisi sırasında Saadettin Bey, can güvenliği açısından tehlikeli gördüğü binaların yıkılması talimatını vermiştir. Deprem sonrasında doktor ve ilaç sıkıntısının yaşandığı görülmektedir. Öyle ki, daha önce de belirtildiği üzere Isparta'da bulunan üç-dört doktor 17 Ocaktan itibaren farklı semtlerde çadırlarda yaşamaya başlayan evsiz afetzedeler ile birkaç yaralının muayenesiyle ilgilenmiştir. Mutasarrıfla beraber yıkık mahallelerde dolaşan memleket tabibi de tedaviye ihtiyacı olan afetzedelerin muayene ve bakımlarını gerçekleştirmiştir. Yaralılar için gerekli ilaçlar ise şehirdeki Doktor Macaraki Eczanesinden karşılanmıştır. Bunların yanı sıra depremden etkilenen iki köye de memurlar gönderilerek hasar tespiti yapılmış ve afetzedelerin ihtiyaçları belirlenmeye çalışılmıştır (BOA,Y.PRK.UM., 13/112, 16 CA 1306; Y.MTV., 37/36, 22 CA 1306).

Deprem sonrasında evleri yıkılarak açıkta kalan afetzedelerin küçük bir kısmı akrabalarının yanına yerleşirken, önemli bölümü askeri makamlardan mümkün mertebe temin edilen çadırlara yerleştirilmiştir. Bu bağlamda afet komisyonu tarafından Isparta askeri depolarından temin edilen 80 çadırın afetzedeler için kullanıldığ görülmektedir. Ayrıca Konya Valisi Memduh Bey'in Teke Mutasarrıfına, evleri yıkılan depremzedelerin barındırılması için çadır göndermesi talimatını vermesi, bahsi geçen miktardaki çadırın yetmediğini ve Isparta dışından da çadır getirtildiğini göstermektedir (BOA,Y.PRK.UM., 13/112, 16 CA 1306; Y.MTV., 37/36, 22 CA 1306).

Afet Komisyonu, yıkılan ve hasar gören binaların ne kadar masrafla inşa ve tamir edilebileceğini belirlemek üzere teknik bir heyete inceleme yaptırmıştır. Bu inceleme neticesinde hafif derecede hasar gören ve içinde oturulabilecek evlerin dışındaki 252 evin tamir ya da yeniden inşasına karar verilmiştir. Birer ya da ikişer oda olarak inşa edilmesi kararlaştııılan bu evlerin masrafı 99.895 kuruş tutmuştur. Bu paranın 48.500 kuruşu yeni yapılacak evlerin inşasına; 49.235 kuruşu hasar gören evlerin tamirine; geri kalan 1.150 kuruşu ise tehlike arz eden evlerin yıkılması ve enkazının kaldırılmasına tahsis edilmiştir. Sadece maddi durumu iyi olmayan fakir depremzedelere değil, maddi durumu iyi olan depremzedelere de yardım edildiği görülmektedir. Öyle ki bahsi geçen 99.895 kuruşun 57.070 kuruşu maddi durumu kötü olan 157 ailenin zarar gören evleri için kullanılırken, geri kalan 42.825 kuruşu maddi durumu iyi olan 95 depremzede ev sahibinin evlerinin inşaatına tahsis edilmiştir. Bu bilgiden yola çıkarak depremin daha çok, \% 62'lik oranla fakir aileleri etkilediğini söylenebilir (BOA,Y.MTV., 37/36, 22 CA 1306).

Binaların tamiri veya yeniden inşasına geçildiğinde Isparta'daki duvarcı ustalarının yetmediği görülmüştür. Bu nedenle sancağa bağlı Eğirdir kazası ile Burdur livasından bir miktar duvarcı ustasının gönderilmesi talep edilmiştir (Y.MTV., 37/36, 22 CA 1306). Buna rağmen kısa bir süre içerisinde, 23 Ocak 1889 tarihinde, Padişahın ihsanı ve toplanan yardım paraları ile evlerin inşasına başlanmıştır (BOA,Y.MTV., 37/36, 22 CA 1306).

Isparta mutasarrıfının, deprem sonrasında her gün ya da gün aşırı olarak vilayet merkezi ile merkezi hükümeti bilgilendirdiği görülmektedir. Bununla birlikte depremin hemen sonrasında Isparta Mutasarrıflığ ile bağlı olduğu Konya Valiliği arasında bir iletişim sıkıntısının yaşandığı anlaşılmaktadır. Öyle ki Konya Valisi Memduh Bey, Mabeyn-i Hümayun Başkitabetine hitaben yazdığı 17 Ocak 1889 tarihli yazısında, Isparta mutasarrıfının henüz deprem hakkında izahatta (tafsilat) bulunmadığından dolayı kendisini 
telgrafhaneye çağırttığını ifade etmektedir (BOA, Y.MTV., 37/36, 22 CA 1306; Y.PRK.UM., 13/112, 16 CA 1306).

Yardım Faaliyetleri: Deprem sonrasında afetzedelerin acil ihtiyaçlarının karşılanması için dönemin padişahı Sultan II. Abdülhamit tarafından 300 lira ihsan edilmiştir. Ayrıca daha önce Kadıköy yangınzedeleri için toplanan ihtiyaç fazlası 10.000 kuruşun da Isparta depremzedeleri için kullanılmasına karar verilmiştir. Bunların yanı sıra padişahın fermanı üzerine Konya vilayeti merkezi ile buraya bağlı Teke, Niğde ve Burdur sancaklarında depremzedeler için yardım kampanyaları başlatılmıştır. Teke sancağı hayırseverleri 672 Mecidiye yardım etmişlerdir. The Levant Herald gazetesinin 3 Mart 1889 tarihli nüshasındaki bilgilere göre ise bu tarih itibariyle Konya vilayeti genelinde 1072 gümüş Mecidiye toplanmıştır (BOA,Y.PRK.UM., 13/112, 16 CA 1306; DH.MKT., 1608/16, 19 B 1306; Y.MTV., 37/36, 22 CA 1306; The Levant Herald, Vol IX, say1 9, 3 Mart 1889).

Bu yardım paraları ile Isparta'da depremde yıkılan ya da hasar gören 800 kadar ev yeniden inşa ya da tamir edilmiştir. Evlerin inşaatının 1890 yılı Mayıs ayı itibari ile bitirildiği görülmektedir. Bu vesile ile halk, Konya valisinin Isparta'yı ziyareti sırasında Padişaha hayır dualarında bulunarak, onu minnetle anmıştır. Ayrıca Isparta Sancak İdare Meclisi üyeleri de, düzenledikleri mahzar ile yaptığı yardımlardan ötürü dönemin padişahı Sultan II. Abdülhamit'e bir buçuk sayfa boyunca teşekkür ve hayır duada bulunmuşlardır (BOA,Y.PRK.UM., 13/112, 16 CA 1306; Sabah, 269: 9 L 1307).

\section{Mart 1889 Isparta Depremi}

The Levant Herald gazetesinin 10 Mart 1889 tarihli sayısında "geçen hafta" meydana geldiğini belirtmesinden, bu depremin Mart ayının başlarında yaşandığı tahmin edilebilir. Artçı şoku yaşanmayan bu deprem hasara yol açmamıştır (The Levant Herald, Vol IX, sayı 10, 10 Mart 1889). Bu depremin, bundan iki ay kadar önce, 17 Ocak 1889 tarihinde yaşanan ve Isparta'da büyük yıkıma sebep olan depreminin artçı şoklarından biri olması da kuvvetle muhtemeldir.

\section{Ekim 1889 Isparta Depremi}

Bu deprem hakkındaki verileri elde ettiğimiz 23 Ekim 1889 tarihli Sabah gazetesi, tam tarihini vermemekle birlikte depremin "geçenlerde meydana geldiğini" belirtmiştir. Akşam ezanından üç saat sonra gelen bu deprem, hafif şiddetli gerçekleşmiş olup, hasara yol açmamıştır (Sabah, sayı 55, 27 S 1307).

\section{Kasım 1889 Isparta Depremi}

Deprem, akşam ezanından üç saat sonra, arşiv belgesinin ifadesiyle "şiddetlice" yaşanmıştır. Deprem can kaybına neden olmamışsa da, yıkılmaya meyilli birkaç duvarın devrilmesiyle sonuçlanmıştır (BOA, Y.PRK.UM., 15/96, 19 RA 1307).

\section{Haziran 1892 Isparta Depremi}

Pazar gecesi alaturka saat 3.00 sularında "şiddetli derecede" meydana gelen bu deprem yaklaşık 10 saniye sürmüştür. Artçı şoku yaşanmayan depremin yönü doğudan batıya doğrudur (Tercüman-1 Hakikat, 4174: 13 ZA 1309).

\section{Haziran 1892 Isparta Depremi}

Aynı gün, yönleri doğudan batıya doğru olan iki deprem ardı ardına yaşanmıştır (The Levant Herald, Vol XII, sayı 21, 20 Haziran 1892).

SEFAD, 2018 (40): 297-312 


\section{Ağustos 1892 Isparta Depremi}

Yönü, doğudan batıya doğru olan bu deprem, Salı günü alaturka saat 4.00 sularında meydana gelmiştir. Ardı ardına meydana gelen iki depremde can kaybı yaşanmamış ise de Dazkırı, Burdur ve Isparta ile buralara bağlı nahiye ve köylerde ağır hasar meydana gelmiştir. Dazkırı nahiyesine bağlı Başmakçı köyünde 110 evin tamamen, 191 evin kısmen yıkılmasına yol açan, Burdur da ise hükümet konağında, erkek ve kadın hapishanelerinde, sıbyan mektebinde, iki cami minaresinde ve 53 evde ağır hasara yol açan deprem, Isparta'da da bazı hasarlar meydana getirmiştir (BOA,Y.PRK.DH., 5/59, 18 S 1310; DH.MKT., 1992/22, 3 S 1310; Y.PRK.SRN., 3/50, 1 S 1310; Y.A.HUS., 264/130, 19 S 1310; The Levant Herald, Vol XII, 31: 5 Eylül 1892).

Isparta'da depremin ağır hasara yol açtığı binalardan birisi hükümet konağıdır (BOA, DH.MKT., 2027/39, 14 CA 1310; DH.MKT., 2057/117, 15 Ş 1310). Gerek harem gerekse resmi odaları bir iki asırlık köhne ve harap bir halde bulunan (Böcüzâde Süleyman Sami 2012: 548549) Isparta hükümet konağı, depremde biraz daha hasar görmüş olup, tamir masrafı olan 8.000 kuruş tutmuştur. Bu meblağ, vilayet bütçesinde tamir işleri için karşılık olmaması ve 1308 senesi Dâhiliye Zuhurat Tertibi'nde para bulunmaması nedeniyle 1308 senesi bütçe açığına ve zuhurat tertibi fazlasına kaydedilmiş̧ir. (BOA, DH.MKT., 2027/39, 14 CA 1310; DH.MKT., 2057/117, 15 Ş 1310).

$\mathrm{Bu}$ şiddetli depremin Isparta'da artçı şokları da yaşanmıştır. 26 Ağustos tarihinde hafif şiddetli yaşanan depremi, 27 Ağustos ve sonrasında meydana gelen diğer artçı şoklar takip etmiştir (The Levant Herald, Vol XII, 31: 5 Eylül 1892).

\section{6 Şubat 1894 Isparta Depremi}

The Levant Herald gazetesi 26 Şubat 1894 tarihinde Isparta'da bir deprem yaşandığından bahsetmişse de ayrıntılı bilgi vermemiştir. Bu bağlamda depremin hafif şiddetli yaşandığı ve hasara yol açmadı $\breve{1} 1$ tahmin edilebilir (The Levant Herald, Vol XIV, 9: 5 Mart 1894).

\section{Kasım 1894 Isparta Depremi}

Alaturka saat $8.30^{\prime}$ da hafif şiddetli derecede meydana gelen bu deprem hasara yol açmamıştır (İkdam, 1943: 26 B 1317).

\section{Şubat 1896 Isparta Depremi}

İkdam gazetesi, 14 Şubat 1896 tarihli nüshasında Isparta' da "ahiren (son zamanlarda)" bir deprem meydana geldiğinden bahsetmekle birlikte kesin tarihini paylaşmamıştır. Şubat ayı başlarında yaşandığı tahmin edilen bu deprem, hasara yol açmamıştır (İkdâm, 561: 29 Ş 1313).

\section{Eylül 1898 Isparta Depremi}

The Levant Herald gazetesi, 5 ve 6 Eylül tarihlerinde Isparta, Denizli ve Adilcevaz'da deprem yaşandığı bilgisini vermişse de ayrıntılı bilgi paylaşmamıştır (The Levant Herald, Vol XVIII, 37: 12 Eylül 1898).

\section{Eylül 1899 Isparta Depremi}

Ahenk gazetesinin "iyice dehşetli bir zelzele" olarak tanımladığı bu deprem, sabaha doğru, alaturka saat 10.00 'da meydana gelmiştir. Deprem beş saniyeden fazla sürmüşse de hasara yol açmamıştır (Ahenk, 945: 19 CA 1317). 


\section{Kasım 1899 Isparta Depremi}

Gece saat 8.30 'da meydana gelen bu deprem, hafif şiddetlidir. Hasara yol açmayan depremin artçı şokları 2 Aralık 1900 tarihine kadar devam etmiştir (Tercüman-ı Hakikat, 6684: 28 B 17; İkdam, 1943: 26 B 1317; Ahenk, 999: 23 B 1317).

\section{SONUÇ}

19. yüzyılın ikinci yarısı boyunca Isparta ve ilçelerinde yirmi beş deprem yaşandığı tespit edilmiştir. Bununla birlikte ulaşılamayan depremlerin de var olabileceği düşünülerek, bu rakamın en asgari sayıyı temsil ettiğini belirtmek gerekir. 18 Mayıs 1851'de Sütçüler'de, 11 Aralık 1883'te Keçiborlu'da, 17 Ocak 1889, 10 Kasım 1889 ve 23 Ağustos 1892 tarihlerinde Isparta'da meydana gelen beş depremin hasara yol açtığı, bunların dışındaki bazı depremlerin de çok şiddetli derecede hissedilerek, halkta heyecan, korku ve endişenin yaşanmasına sebep olduğu görülmüştür.

Hasara yol açan beş deprem içerisinde en büyüğü 17 Ocak 1889 depremi olup, Isparta şehir merkezi ile buraya bağlı bazı köylerde çok sayıda binanın harap olmasıyla sonuçlanmıştır. İki kişinin hayatını kaybettiği, iki kişinin de yaralandığı bu depremde 800 kadar bina etkilenmekle birlikte bunların 313'ü yıkılmış ya ada ağır hasar görerek, kullanılmaz hale gelmiştir. Geri kalan 500 civarında bina ise içinde oturulabilecek derecede hafif hasar görmüştür. Bu şiddetli deprem, Isparta şehir merkezinde başta Hacı Elfı (Pirimehmet), Şeyh (Kutlubey) mahalleleri olmak üzere, Sülübey, Emre, Tekye (Hızırbey), Cami-i Atik (Kutlubey) ve Yaylazade (Yayla) mahallelerini ile Deregümü köyünde etkili olmuştur.

17 Ocak 1889 depremi sonrasında Isparta Mutasarrıfı Saadettin Bey’in başkanlığında kurulan Afet Komisyonu, hasar tespiti yaptıktan sonra afetzedelerin barınma ve beslenmeleri, yaralıların tedavisi, tehlike arz eden binaların yıkılması, hasar gören binaların tamiri ya da yeniden inşası gibi birçok önemli görevi, acil bir şekilde yerine getirmeye çalışmıştır.

$\mathrm{Bu}$ deprem sonrasında Konya vilayet merkezi ve bağlı sancaklarda afetzedeler adına yardım kampanyaları başlatıldığı gibi dönemin padişahı Sultan II. Abdülhamit de 300 lira ihsanda bulunarak depremzede tebaasının yanında olduğunu hissettirmiştir. Bu paralarla afetzedelerin acil ihtiyaçları karşılandı̆̆ı gibi, hasar gören 800 kadar depremzede evinin tamiri ya da yeniden inşası gerçekleştirilmiştir. Bahsi geçen evlerin inşaatı 1890 yılı Mayıs ayı itibari ile bitirilerek, depremzedelerin kalıcı iskânları sağlanmıştır. Isparta yöneticileri, ileri gelenleri ve halkı, yapılan yardımlar karşısında Padişaha teşekkür ederek, hayır dualarını ondan esirgememişlerdir.

\section{SUMMARY}

Natural disasters are significant socio-economic events that concern people and states. This is because it is not possible or takes a long time for the people, the settlement units, the environment and the economic activities to return to the pre-disaster conditions due to the significant natural disasters. For this reason, the effects of natural disasters need to be revealed for a complete understanding of the social and economic history of a state or city.

In this study, the earthquakes that took place during the second half of the 19th century in the Isparta provinces and districts located in the first-degree earthquake region

SEFAD, 2018 (40): 297-312 
were discussed in the light of primary sources, which are archive documents, newspapers and chronicles. In this way, it has been aimed to contribute to the seismicity and Isparta's earthquake history by revealing how frequently and large earthquakes were experienced. In this context, during the second half of the 19th century in Isparta, it was determined that twenty-five earthquakes occured, several of which seemed to have caused damage. The earthquakes which took place in Sütçüler on 18 May 1851, Keçiborlu on 11 December 1883, Isparta on 17 January 1889, Isparta on 10 November 1889, Isparta on 23 August 1892 caused a lot of the damages. Especially on 17 January 1889, the earthquake was very severe. So, several buildings in Isparta city centre and some villages connected here were ruined. In this earthquake, 313 of the buildings in Isparta were destroyed or seriously damaged and became unusable. About 500 of them were also slightly damaged.

The disaster commission, established after the earthquake on 17 January 1889 under the chairmanship of Isparta Saadettin Bey, realized a damage detection right after the earthquake and tried to fullfill urgent tasks such as the treatment and feeding of the victims, the treatment of the wounded, the destruction of the dangerous buildings, the repair or reconstruction of the damaged buildings. After the earthquake, aid campaigns were initiated for disaster victims within the province of Konya. Also, Sultan II Abdülhamit helped 300 lira for aid campaigns. With this money, the emergency needs of the victims were met, and the 800 damaged homes were repaired or reconstructed. The construction of the mentioned houses was completed as of May 1890, and permanent residence was provided for the earthquake victims. The Isparta administrators, the elders and the people, thanked and prayed for the assistance made by the Sultan. 
KAYNAKÇA

Başbakanlık Osmanlı Arşivi (BOA)

Bab-1 Ali Evrak Odası (BEO.) 508/38081, 4 CA 1312; 513/38438, 11 CA 1312.

Dahiliye Nezareti Mektubi Kalemi (DH.MKT.), 1608/16, 19 B 1306; 2027/39, 14 Ca 1310; 2057/117, 15 Ş 1310; 2252/27, 22 CA 1317.

İrade Hususiye (İ.HUS.) 26/63, 14 M 1312.

Sadaret Mektubi Kalemi Deavi Evrakı (A.MKT.DV.), 38/68, 29 Ş 1267.

Sadaret Mektubi Mühimme Kalemi Evrakı (A.MKT.MHM.), 420/87, 04 C 1285; 422/22, 12 C 1285.

Yıldız Mütenevvi Maruzat Evrakı (Y.MTV.), 37/36, 22 CA 1306; 197/36, 5 Ş 1317.

Yıldız Perakende Evrakı Dahiliye Nezareti Maruzatı (Y.PRK.DH.), 1/64, 12 S 1301; 5/59, 18 S 1310; 1992/22, 3 S 1310.

Yıldız Perakende Evrakı Serkurenalık Evrakı (Y.PRK.SRN.), 3/50, 1 S 1310.

Yıldız Perakende Evrakı Umumi (Y.PRK.UM.), 13/112, 16 CA 1306; 14/2, 4 C 1306; 15/96, 19 RA 1307.

Yıldız Sadaret Hususi Maruzat Evrakı (Y.A.HUS.), 207/30, 14 M 1305; 207/83, 7 S 1305; 264/130, 19 S 1310.

\section{Süreli Yayınlar}

Ahenk, say1 945, 19 CA 1317; sayı 999, 23 B 1317.

Basiret, sayı 1528-1535: 13-21 R 1292; 1540: 23 R 1292.

Ceride-i Havâdis, sayı 197: 22 N 1260; 534: 6 Ş 1267; 733-738: 28 C-8 Ş 1271; 863: 14 R 1274; 1059: 24 RA 1278;

İkdâm, sayı 561, 29 Ş 1313; sayı 1943, 26 B 1317.

Ruznâme-i Ceride-i Havâdis, 545: 16 B 1279.

Sabah, sayı 55, 27 S 1307; sayı 269, 9 L 1307.

Takvim-i Vekâyi, 678: 21 B 1279.

Tarîk, sayı 593, 10 S 1303; sayı 1272, 23 M 1305.

Tercüman-1 Hakikat, sayı 4174, 13 ZA 1309; sayı 6684, 28 B 17; sayı 1943, 26 B 1317.

The Levant Herald, Vol III, 4: 28 Ocak 1874; Vol IX, sayı 5-6, 3-10 Şubat 1889; sayı 9-10, 3-10 Mart 1889; Vol XII, sayı 21, 20 Haziran 1892; sayı 31, 5 Eylül 1892; Vol XIV, say1 9, 5 Mart 1894; Vol XVIII, sayı 37, 12 Eylül 1898.

\section{Kitap ve Makaleler}

Böcüzâde Süleyman Sami (2012). Isparta Tarihi. (haz. Hasan Babacan). Isparta: Isparta Valiliği İl Kültür Müdürlüğ̈̈.

Ambraseys,, Nicholas (2009). Earthquakes in the Mediterranean and Middle East A Multidisciplinary Study of Seismicity up to 1900, London: Imperial College Press.

Dizer, Muammer (1986). Astronomi Hazineleri, İstanbul: Boğaziçi Üniversitesi Yayınları.

Görmüş, Muhittin-Kanbur, Zakir vd. (2010). "Isparta ve Çevresinin Depremselliği Üzerine”. SDUGEO 1 (3): 21-27.

Özey, Ramazan (2011). Afetler Coğrafyası. İstanbul: Aktif Yayınevi.

Sakin, Orhan (2009). "Osmanlı Döneminde İstanbul'da Deprem", Afetlerin Gölgesinde İstanbul, ed. Sait Öztürk, İstanbul: İstanbul Büyükşehir Belediyesi Yayınları.

Sargın, Sevil (2004). "Isparta Yöresinde Fiziki Çevre Faktörlerinin Yerleşme Birimleri Üzerindeki Etkisi”. Doğu Coğrafya Dergisi 11: 371-388.

SEFAD, 2018 (40): 297-312 
Satılmış, Selahattin (2016). "30 Eylül 1887 Banaz Depremi". Süleyman Demirel Üniversitesi Fen-Edebiyat Fakültesi Sosyal Bilimler Dergisi (38): 79-98.

Sezer, Lütfi İhsan (2000). “Isparta-Burdur Sismotektonik Yöresinde Depremsellik ve Deprem Riski”. Ege Coğrafya Dergisi (11): 75-96.

Şahin, Cemalettin-Sipahioğlu, Şengün (1991). Türkiye Afetler Coğrafyast. Ankara: Gündüz Eğitim ve Yayınları.

Ünver, Suheyl A. (2014). İstanbul Rasathanesi, Ankara: TTK Yayınları.

Yazıcı, Nesimi (2003). Ocak 1898 Balıkesir Depremi ve Sonrası, Ankara.

\section{İnternet Kaynakları}

http://www.e-sehir.com/turkiye-haritasi/isparta-deprem-fay-hatti-riskharitasi.html [06.02.2018]

http://www.koeri.boun.edu.tr/140yil/Tr/kandilli.asp?PageName=tarihce 